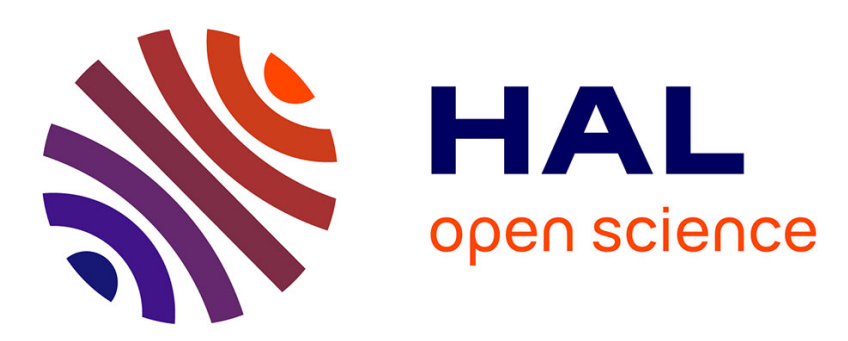

\title{
Solubilization and purification of the gonadotropin (GtH2) receptor from rainbow trout (Oncorhynchus mykiss) ovaries
}

\author{
Hélène Quesnel, Bernard Breton
}

\section{- To cite this version:}

Hélène Quesnel, Bernard Breton. Solubilization and purification of the gonadotropin (GtH2) receptor from rainbow trout (Oncorhynchus mykiss) ovaries. General and Comparative Endocrinology, 1993, 91, pp.272-280. 10.1006/gcen.1993.1127 . hal-02715348

\section{HAL Id: hal-02715348 \\ https://hal.inrae.fr/hal-02715348}

Submitted on 1 Jun 2020

HAL is a multi-disciplinary open access archive for the deposit and dissemination of scientific research documents, whether they are published or not. The documents may come from teaching and research institutions in France or abroad, or from public or private research centers.
L'archive ouverte pluridisciplinaire HAL, est destinée au dépôt et à la diffusion de documents scientifiques de niveau recherche, publiés ou non, émanant des établissements d'enseignement et de recherche français ou étrangers, des laboratoires publics ou privés. 


\title{
Solubilization and Purification of the Gonadotropin (GTH II) Receptor from Rainbow Trout (Oncorhynchus mykiss) Ovaries
}

\author{
Helene Quesnel and Bernard Breton' \\ Laboratoire de Physiologie des Poissons, INRA, Campus de Beaulieu, F 35042 Rennes Cédex, France
}

Accepted April 20, 1993

\begin{abstract}
The rainbow trout (Oncolynchus mykiss) ovarian gonadotropin (GTH II) receptor was solubilized by extraction with the nonionic detergent $1 \%$ Triton $\mathrm{X}-100$ in the presence of $20 \%$ glycerol. The homone-binding chatacteristics of the soluble receptors were similar to those of menbrane-bonnd receptors: the Scatchard plot of the equilibrium binding data produced a straight line. suggesting that the solubilized GTH $I 1$ receptors. like membranebound receptors, contained a single class of high affinity ${ }^{125}$ I-sGTH 11 binding siles with an association constant of $2-5 \times 10^{10} M^{-1}\left(K_{\mathrm{a}}=1.4-2 \times 10^{10} \mathrm{M}^{-1}\right.$ for membrane-bound receptor). The maximal binding capacity was very low and varied from 7 to $17 \mathrm{fmol} / \mathrm{mg}$ proteins (about $5 \mathrm{fmol} / \mathrm{mg}$ ovarian membrane protein). The soluble receptor was purified by a simple and rapid immunoaffinity chromatography. The sGTH ll-solubilized receptor conplex was adsorbed to anti-sGTH II $\beta$-subunit gammaglobulins covalently linked to Sepharose $4 B$ and then eluled with an acidic buffer. About $50 \%$ of the binding aclivity present in the Triton X-100 extract was tecovered in the pH 4 eluate. The other binding sites were eluted as a hormone-receplor complex and/or a damaged form. The free purified receptor presented a $K_{\mathrm{i}}$ of $1.3 \times 10^{16} \mathrm{M}^{-1}$ in agreement with those found in membrane preparation and solubilized extract. 1993 Acadentic Press, Inc.
\end{abstract}

In salmonids the maturational gonadotropin (CTHII) is involved in the regulation of female gametogenesis (Nagahama, 1983; Breton et al., 1983). The circulating GTH II concentrations vary during induction of exogenous vitellogenesis and the final stage of oocyte maturation (Breton et al., 1983). Plasma G'TH 11 levels are very low at the begimning of the vitellogenesis, increase at the end of the vitellogenesis, before oocyte maturation, reach a maximum after the ovulation, and then decrease. Short-term studies showed the presence of either daily or pulsatile rhythms of GTH II secretion, according to gametogenic stage (Zohar et al., 1986a,b). These rhythms are linked to the effects of the hormone on ovarian steroidogenesis. In trout, during vitellogenesis pulsatile Gill II secretion induces a high concentration of estradiol; during the peri-

1 To whom requests for reprints should be addressed. ovulatory period the circadian rhythm of GTH II secretion participates in the inhibition of aromatase activity (Young et al., 1983), resulting in a decrease in estradiol secretion and stimulates the production of the meiosis inducing steroid, $17 \alpha, 20 \beta$-dihydroxy-4-pregnen-3-one (Zohar et al., 1986b). These results emphasize the importance of secretory rhythms in the local action of GTH II and its regulation at the receptor levei. As in other vertebrates, the first step of the GTH 11 action is to bind to specific ovarian receptors to evoke an intracellular cascade.

The presence of gonadotropin receptors in gonadal tissue has been reported: either using hCG binding in testes (Schlaghecke, 1983; Schulz and Schlaghecke, 1984) and in preovulatory ovary (Schulz at. al., 1985) of rainbow trout (Oncorlynchus mykiss), or using GTH II specific binding in immature ovary and testes of chum salmon Oncorhynchus keta (Van der Kraak and Donald- 
son, 1982; Van der Kraak, 1983), in the preovulatory (Kanamori and Nagahama, 1988) and postovulatory ovary (Kanamori et al., 1987) of amago salmon (Oncorhynchus rhodurus), in the ovary (Breton et al., 1986; Breton and Sambroni, 1989) and in testes (Le Gac et al., 1988) of brown trout (Salmo trutta L.) and postovulatory ovary of rainbow trout (Quesnel and Breton, 1992). Other data report the evolution in the number and affinity of these receptors during the gametogenesis. In rainbow trout, the number of testicular GTH II binding sites was very low in regressed testis, increased during gametogenesis and was at a maximum just before and during spermiation (Le Gac and Fostier, 1987). In the brown trout ovary, the number of binding sites per milligram of membrane protein increased significantly during the initiation of the synthesis and the incorporation of vitellogenin. It was stable and lower during vitellogenesis and was about 10 times higher at the time of ovulation. During the periovulatory period, the affinity coefficient doubled (Breton and Sambroni, 1989). In amago salmon, the number of GTH II receptors increased in the follicles in keeping with the developmental changes in follicular steroidogenesis in response to gonadotropin (Kanamori and Nagahama, 1988).

Recently, GTH I and GTH II receptors have been demonstrated in coho salmon postovulatory ovarian membrane preparation (Yan et al., 1991) and in granulosa cells and the thecal layer (Yan et al., 1992).

However, to date there are no data on the structure and properties of these receptors, since this requires the development of a technique for membrane protein solubilization. This study reports a suitable method to solubilize and investigate the receptor without any loss in binding capacity.

\section{MATERIALS AND METHODS}

\section{Experimental animals}

Two- or three-year-old female rainbow trout $O$. mykiss, from the INRA Gournay fish farm, were kept at $12^{\circ}$ in a recirculating water system until they ovulated.

\section{Preparation of ${ }^{125} I-s G T H I I$}

Maturational salmon gonadotropin (sGTH Il) was purified from pituitary glands of spawning Oncorhynchus tshawytscha (Breton et al., 1976). Pure sGTH II was iodinated by the lactoperoxidase method (Thorell and Johansson, 1971) as modified by Hirano et al. (1985). The following reagents were added in a 5-ml polyethylene tube: $5 \mu \mathrm{g}$ sGTH $\mathrm{II}$ in $5 \mu$ liters $0.05 \mathrm{M}$ phosphate buffer ( $\mathrm{pH} 7.5$ ), $200 \mu \mathrm{Ci}$ carrier-free $\mathrm{Na}^{125} \mathrm{I}$ (IMS-30, Amersham) buffered with $2 \mu$ liters $0.5 \mathrm{M}$ phosphate buffer ( $\mathrm{pH} 7.5$ ), $0.037 \mu \mathrm{g} \mathrm{H}_{2} \mathrm{O}_{2}$ in $5 \mu$ liters $0.2 M$ saline phosphate buffer, $\mathrm{pH} 7.5$, and $0.5 \mu \mathrm{g}$ lactoperoxidase ( $90 \mathrm{U} / \mathrm{mg}$, Sigma) in $5 \mu$ liters $\mathrm{H}_{2} \mathrm{O}$. After 3 min the reaction was stopped by adding 150 $\mu$ liters of $0.2 M$ PBS. Separation of radiolabeled GTH from free ${ }^{125}$ I was carried out by chromatography on an Ultrogel AcA 54 (IBF) column $(1 \times 30 \mathrm{~cm})$. The specific activity was generally between 15 and $25 \mu \mathrm{Ci} /$ $\mu \mathrm{g}$. The iodinated GTH II was stored at $-20^{\circ}$ in the presence of glycerol $(\mathrm{v} / \mathrm{v})$ and used during the 2 weeks after preparation.

\section{Receptor Preparation}

The membrane preparation was obtained employing a modified method from Breton et al. (1986).

The entire procedure was carried out in a cold room $\left(4^{\circ}\right)$ using chilled buffers. Immediately following decapitation of ovulated fish, ovaries were removed and either deep-frozen by plunging them into liquid nitrogen or placed in the homogenization buffer $(0.02 \mathrm{M}$ Tris, $5 \mathrm{mM} \mathrm{MgCl}, 0.15 M$ sucrose, $0.25 \mathrm{mg} / \mathrm{ml}$ trypsin inhibitor, and $1 \mathrm{~m} M$ PMSF at $\mathrm{pH} 7.5$ ). Tissues were chopped and homogenized in a polytron tissue grinder with two successive bursts at high speed ( 1 vol of tissue for $5 \mathrm{vol}$ of buffer). The homogenate was filtered through a cheesecloth and homogenized with five strokes in a glass teflon homogenizer with 0.1 to 0.15 $\mathrm{mm}$ space between the piston and the cylinder. The final homogenate was centrifuged twice at $1000 \mathrm{~g}$ for 10 min at $4^{\circ}$. The supernatant was centrifuged again at $110,000 \mathrm{~g}$ for $1 \mathrm{hr}$ at $4^{\circ}$. The final pellets, which contained the membranes and lysosomes, were resuspended in $0.02 \mathrm{M}$ Tris-5\% glycerol at $\mathrm{pH} 7.5$ and kept at $-20^{\circ}$ until use.

The protein content of the preparations was determined according to Lowry (1951).

\section{Solubilization of sGTH II Receptors}

The $110,000 \mathrm{~g}$ pellets were dissolved in $1 \%(\mathrm{v} / \mathrm{v})$ Triton $\mathrm{X}-100,20 \%(\mathrm{v} / \mathrm{v})$ glycerol in $0.02 \mathrm{M}$ Tris and continuously stirred for $3 \mathrm{hr}$ at $4^{\circ}$. The tubes were centri- 
fuged for $1 \mathrm{hr}$ at $110,000 \mathrm{~g}$ at $4^{\circ}$. The supernatants, which contained the solubilized proteins were collected and frozen at $-20^{\circ}$ for further characterization.

\section{Assay of Solubilized Receptor Binding}

Assays were performed in 5-ml polyethylene tubes containing $150 \mu$ liters of assay buffer $(0.02 M$ Tris, $0.1 \%$ bovine serum albumin, $\mathrm{CaCl}_{2}$ (final concentration of $0.04 M$ ), containing whenever necessary the unlabeled hormone, $50 \mu$ liters of ${ }^{125}$ I-GTH II and 0.3$\mathrm{ml}$ aliquots of solubilized receptor. The assay tubes were kept for $17 \mathrm{hr}$ at $4^{\circ}$, free and bound ${ }^{125} \mathrm{I}-\mathrm{GTH}$ were separated by double precipitation with polyethylene glycol (PEG) (Dufau et al., 1973). Five-tenths of a milligram of bovine gammaglobulins $(0.2 \mathrm{ml}$ of 2.5 mg per ml of solution) were added as a carrier, followed by $0.5 \mathrm{ml}$ of $30 \%$ polyethylene glycol $(\mathrm{w} / \mathrm{v})$. The final concentration of PEG was $12.5 \%$. After stirring for $10 \mathrm{~min}$ at $4^{\circ}$, the tubes were centrifuged at $2000 \mathrm{~g}$ for $10 \mathrm{~min}$ at $4^{\circ}$ and the supernatants removed by aspiration. The pellets were redissolved in $0.9 \mathrm{ml}$ of $0.1 \%$ Triton X-100 in Tris buffer and, after standing for 10 min at $4^{\circ}$, were precipitated again with $0.5 \mathrm{ml}$ of $30 \%$ PEG. This second precipitation was necessary to achieve a satisfactory blank value. After centrifugation and aspiration of the supernatants, the bound hormone present in the pellets was determined by counting radioactivity in a gamma counter.

\section{Solubilized Receptor Binding Studies Using Gel Filtration}

The complexes were obtained by incubation of $1 \mathrm{ml}$ of solubilized receptor preparation with $0.1 \mathrm{ml}$ of TrisBSA-CaCl buffer and $50 \mu$ liters of ${ }^{125}$ I-GTH II. After standing for $17 \mathrm{hr}$ at $4^{\circ}$ and addition of $1 \mathrm{mg}$ of blue dextran, the incubation mixture was applied to a column $(1 \times 30 \mathrm{~cm})$ of Ultrogel AcA 34 (linear fractionation range of $20,000 d$ to $350,000 d$ ), equilibrated with $20 \mathrm{mM}$ Tris buffer pH 7.5 containing $5 \mathrm{mM} \mathrm{MgCl}_{2}$ and $0.1 \%$ Triton X-100. All the separations were performed at $4^{\circ}$. The flow rate was $4 \mathrm{ml} / \mathrm{hr}$. The radioactivity of each fraction was counted in a gamma counter.

\section{Purification of the GTH II-Receptor Complex}

Gammaglobulins prepared against sGTH II $\beta$-subunit were prepared from a rabbit antiserum raised against GTH II using caprilic acid (Steinbuch and Audran, 1969). They were linked to CNBr-activated Sepharose $4 B$ ( $10 \mathrm{mg}$ protein $/ \mathrm{g}$ gel) by incubation for 2 $\mathrm{hr}$ at room temperature, according to the manufacturer's instructions. After several washes, the gel was poured into a $5-\mathrm{ml}$ column.

Triton X-100-solubilized membranes were incubated with ${ }^{125}$ I-sGTH II in the presence of divalent cations and BSA. The sample was applied to the column equilibrated with $0.1 M \mathrm{NaHCO}_{3}-0.5 M \mathrm{NaCl}$ buffer. The gel was washed with the $\mathrm{NaHCO}_{3}-\mathrm{NaCl}$ buffer containing $0.1 \%$ Triton $\mathrm{X}-100$ and $20 \%$ glycerol. The hormone-receptor complex was then eluted by $6 \mathrm{~N} \mathrm{GuCl}-$ $0.1 \%$ Triton $\mathrm{X}-100-20 \%$ glycerol, $\mathrm{pH} 4.0$. Onemilliliter fractions were collected and each fraction was immediately buffered at $\mathrm{pH} 7-7.5$ with $1 \mathrm{M}$ Tris.

The eluted fractions were concentrated by filtration through an Amicon XM 50 membrane (exclusion limit: $50,000 d$ ) and dialyzed against $0.02 M$ Tris containing $0.1 \%$ Triton $\mathrm{X}-100$ and $20 \%$ glycerol.

The binding capacity of the purified sample was determined by RRA, according to Scatchard's (1949) method.

\section{RESULTS}

\section{Solubilization of Ovarian Receptors with Triton $X-100$}

The membrane-bound receptor was solubilized in $1 \%$ Triton $\mathrm{X}-100$ in the presence of $20 \%$ glycerol with a yield ranging from 55 to $130 \%$ of the binding activity present in the membrane fraction.

\section{Solubilized Receptor Binding Studies by Gel Filtration}

The elution profile obtained by gel filtration of ${ }^{125}$ I-GTH II on an Ultrogel AcA 34 in $0.1 \%$ Triton $\mathrm{X}-100$ showed a major radioactive peak and a delayed minor peak, probably due to deiodination of the hormone (Zohar, 1982) (Fig. 1).

When a mixture of iodinated sGTH II and solubilized extract, incubated together for $17 \mathrm{hr}$ at $4^{\circ}$ in the presence of BSA and $\mathrm{CaCl}_{2}$, was applied to the column, the elution profile obtained (Fig. 1) exhibited an initial peak coinciding with the void volume indicated by blue dextran, and a second peak resulting from free radioiodinated hormone. The first peak could be completely abolished by adding an excess of noniodinated $(1 \mu \mathrm{g})$ sGTH II during the incubation of ${ }^{125} \mathrm{I}-\mathrm{GTH}$ II and a solubilized extract (Fig. 1).

\section{Solubilized Receptor Binding Studies by $R R A$}

Receptor binding data were analyzed using the Scatchard method (Scatchard, 


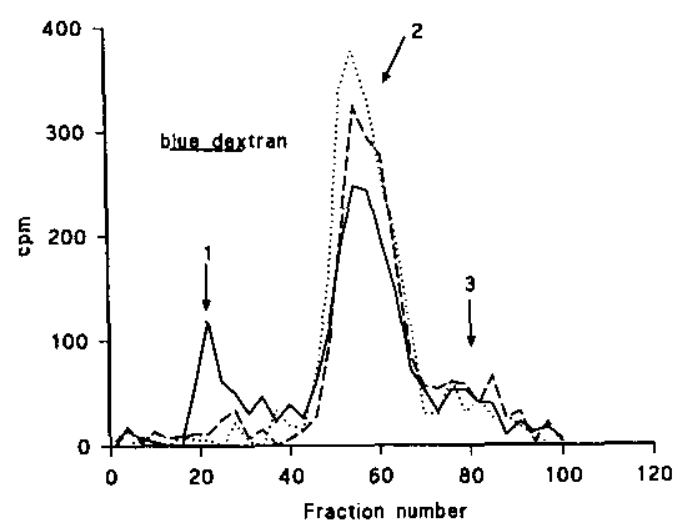

FIG. 1. Elution profile of ${ }^{125}$ I-sGTH II (dotted line) and of ${ }^{125} \mathrm{I}$-sGTH II-receptor complex (solid line) during gel filtration on AcA 34 in the presence of blue dextran. The early peak of radioactivity was completely abolished by prior incubation with sGTH II (dashed line).

1949), in which the ratio of bound to free hormone is plotted against the specifically bound hormone concentration. The plot is a straight line with a slope representing the affinity constant $\left(K_{\mathrm{a}}\right)$. The intercept of this line with the horizontal axis equals the total concentration of binding sites. The membrane fraction exhibited high affinity $\left(K_{\mathrm{a}}=\right.$ $1.4-2 \times 10^{10} M^{-1}$ ) and low capacity (about $5 \mathrm{fmol} / \mathrm{mg}$ ovarian tissue proteins) (data not shown). After solubilization, the Scatchard plot of the equilibrium binding data produced a straight line (Fig. 2), representing a high affinity value $\left(K_{\mathrm{a}}=2-5 \times 10^{10} \mathrm{M}^{-1}\right)$. The maximal binding capacity varied from 7 to $17 \mathrm{fmol} / \mathrm{mg}$ proteins depending on the membrane preparation utilized.

\section{Purification}

In preliminary experiments, it was shown that $90 \%$ of ${ }^{125} \mathrm{I}$-sGTH II, used as tracer, was retained in this column. The elution of this radioactivity was incomplete when using $4 N \mathrm{GuCl}, \mathrm{pH} 4.0$, and reached $80-100 \%$ using $6 \mathrm{~N} \mathrm{GuCl}$, pH 4.0 (Fig. 3).

The GTH II-receptor complex was eluted from the immunoaffinity matrix by 6 $N \mathrm{GuCl}$, pH 4.0 (Fig. 4). The eluate was

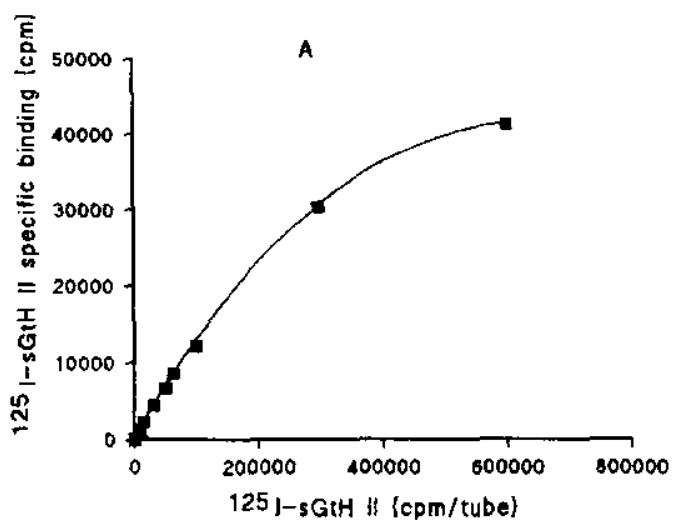

B

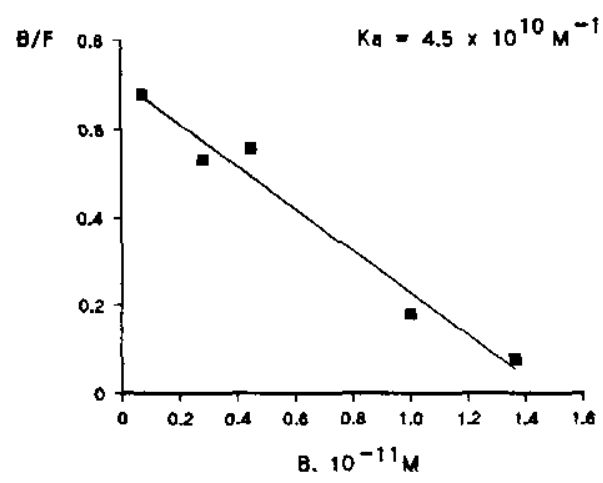

FIG. 2. Equilibrium binding of ${ }^{125} \mathbf{I - s G T H}$ ll to solubilized sGTH II receptor. Detergent-solubilized sGTH II receptors were incubated for $18 \mathrm{hr}$ at $4^{\circ}$ with a constant amount of unlabeled GTH II and increasing amounts of labeled sGTH II. All assays were done in triplicate. The data presented are from a representative experiment. $K_{\mathrm{a}}$, affinity constant.

dialyzed against a Tris buffer containing $0.1 \%$ Triton $\mathrm{X}-100$ and $1 \%$ glycerol and concentrated by filtration through an Amicon XM 50 membrane. Ninety percent of the radioactivity was retained by the membrane. The incubation of the $\mathrm{pH} 4$ eluate with an excess of unlabeled sGTH II resulted in a displacement of $44 \%$ of the radioactivity, indicating the presence of nondissociated complexes in the eluate.

The binding characteristics of the free receptors were determined from a saturation experiment (Fig. 5). Analysis according to 


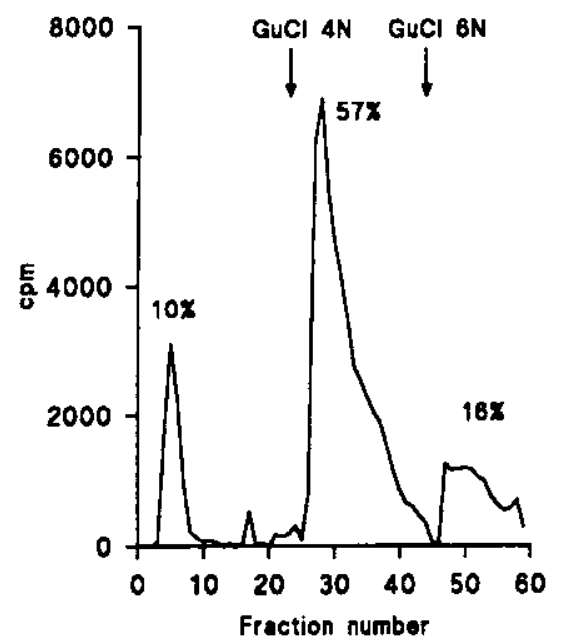

FIG. 3. Elution profile of ${ }^{125} \mathrm{I}-\mathrm{sGTH}$ II alone on immobilized anti- $\beta$ GTH II gammaglobulins.

the Scatchard equation showed that the purified receptor bound $\mathrm{sGTH}$ II specifically with a $K_{\mathrm{a}}$ value of $1.3 \times 10^{10} \mathrm{M}^{-1}$ which is of the same order as that found in membrane preparation and solubilized extract. The binding capacity was not calculated because the very small amount of proteins in the eluate was not measurable using the Lowry's method or other usual methods. Table 1 summarizes receptor purification.

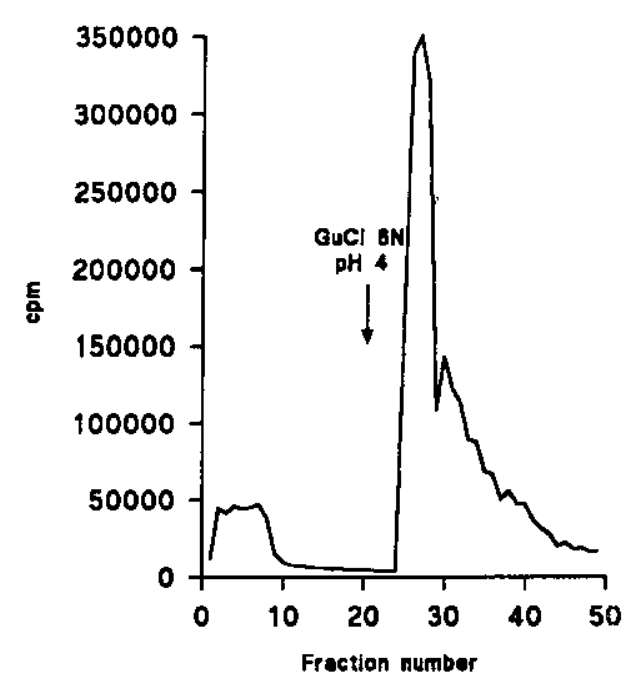

FIG. 4. Elution profile of ${ }^{125} \mathrm{I}-\mathrm{sGTH}$ II-solubilized receptor complex by immunoaffinity chromatography on immobilized anti- $\beta$ GTH II gammaglobulins.
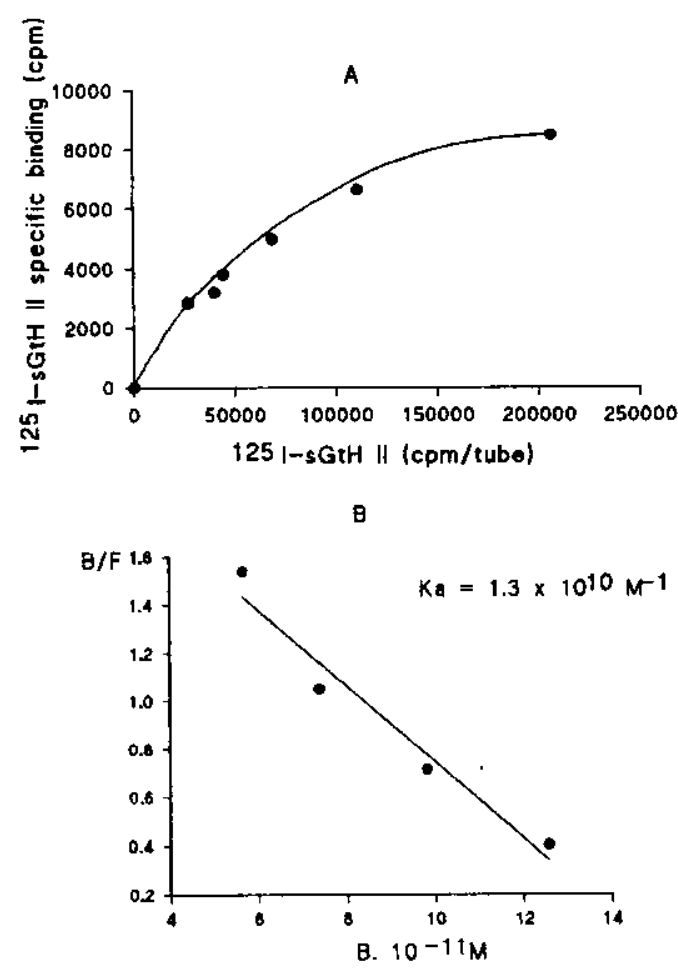

FIG. 5. Equilibrium binding of ${ }^{125}$ I-sGTH II to affinity-purified GTH II receptor and Scatchard plot. Fifty microliters of purified GTH II receptor were incubated for ${ }^{125} \mathrm{I}$-sGTH II binding with increasing amounts of ${ }^{125} \mathrm{I}-\mathrm{sGTH} \mathrm{Il}$ and fixed amounts of unlabeled GTH II. All assays were done in triplicate.

The binding activity recovery was about $50 \%$ from Triton X-100-solubilized preparations.

\section{DISCUSSION}

This study shows that the ovarian GTH II receptor of rainbow trout can be solubi-

TABLE 1

Recovery of the OVARIAN GtH II Receptor AT Each Purification Step on IMMUNOAFFINITY CHROMATOGRAPHY

\begin{tabular}{lcccc}
\hline & $\begin{array}{c}\text { Protein } \\
\text { (mg) }\end{array}$ & $\begin{array}{c}\text { Activity } \\
\text { (fmol) }\end{array}$ & $\begin{array}{c}\text { Specific } \\
\text { activity } \\
\text { (fmol/mg) }\end{array}$ & $\begin{array}{c}\text { Yield } \\
(\%)\end{array}$ \\
\hline $\begin{array}{c}\text { Membrane } \\
\text { pellet }\end{array}$ & 470 & 2350 & 5 & 100 \\
$\begin{array}{c}\text { Triton X-100 } \\
\text { extract }\end{array}$ & 226 & 1717 & 7.6 & $\begin{array}{l}73(100) \\
\text { pH 4 eluate }\end{array}$ \\
\hline
\end{tabular}


lized in an active and stable form, and purified by immunoaffinity chromatography on gammaglobulins prepared against sGTH II $\beta$-subunit.

In the present studies, the starting material was the postovulatory ovary. In this tissue, the number of receptor sites per milligram of membrane protein that increase during initiation of synthesis and the incorporation of vitellogenin remain lower during vitellogenesis and are about 10 times greater at the time of ovulation (Breton and Sambroni, 1989); postovulatory tissue may be the richest source of free binding sites. On another hand, it is devoid of vitellus, which contains much proteolytic activity (Breton et al., 1986) and affects the iodinated GTH II in the radioreceptor assay, giving high values of nonspecific binding. It should be noted that the exact ovulation time for each fish was not defined exactly, ovaries being taken between 1 and 8 days after ovulation, and this could explain the variations in the maximal binding capacity in the membrane and solubilized fractions.

The free receptors were solubilized by extraction with a nonionic detergent, $1 \%$ Triton X-100. The solubilization was first studied by gel filtration on an Ultrogel AcA 34. The elution profile of the solubilized extract, incubated with labeled sGTH II, presented three peaks of radioactivity: one being the hormone-receptor complex, another the unbound GTH II, and the last may be free iodine. Indeed, while studying the preservation of labeled GTH II at low temperature, Zohar (1982) demonstrated that GTH II storage was accompanied by some deiodination of the hormone, which appeared as a radioactive peak after a ${ }^{125} \mathrm{I}$ GTH II peak in gel filtration. The first peak could be eliminated by prior incubation with unlabeled sGTH II. There may thus be competition between labeled and unlabeled hormones during incubation with the solubilized extract. The early peak of radioactivity may therefore correspond to the soluble ${ }^{125} \mathrm{I}$-sGTH II-receptor complex.
Receptors were extracted and stored in the presence of $20 \%$ glycerol to stabilize the free soluble receptors. The preservative action of glycerol on solubilized mammalian gonadotropin receptors has been noted by Dias et al. (1981) for testicular calf FSH receptors and by Ascoli (1983) for mouse Leydig tumor cell LH receptors. The mechanism of glycerol stabilization of the soluble receptors is not known. Timasheff $e t$ al. (1976) suggested that it may be due to enhanced hydrophobic interactions necessary for subunit associations. This suggestion is unlikely since the preservative action of glycerol applies to the $\mathrm{LH}$ receptor, a monomeric form of receptor (Loosfelt et al., 1989; Mc Farland et al., 1989; Minegishi, 1990).

The yields of solubilized binding activity ranged from 55 to $130 \%$. In the rat, Keinänen and Rajaniemi (1986) showed that the membrane-bound hormone-ovarianlutropin receptor complex was partially resistant to chymotrypsin digestion and that this chymotrypsin-resistant fraction was increased by passing the membrane preparation through ConA-Sepharose before proteolytic treatment. This suggested the presence of receptor-containing inverted vesicles in the membrane preparation, thereby underestimating the particulate receptor. Such findings may explain the yields exceeding $100 \%$ in the solubilization step and may also be related to the higher ${ }^{125}$ I-GTH II binding to receptors prepared in $20 \%$ glycerol compared with those prepared in 5\% glycerol (as in membranebound receptors-data not shown). This effect was also seen in solubilized extracts from mouse Leydig cells (Ascoli, 1983).

The hormone-binding characteristics of the soluble receptors were similar to those of membrane-bound receptors. The Scatchard plot of the equilibrium binding data produced a single straight line, suggesting that the solubilized GTH II receptors, like membrane GTH II receptors, contained a single class of high affinity ${ }^{125} \mathrm{I}-\mathrm{sGTH}$ II binding 
sites. The solubilized receptor affinity constant $\left(K_{\mathrm{a}}=2-5 \times 10^{10} \mathrm{M}^{-1}\right)$ was slightly higher than that calculated for membranebound receptors $\left(K_{\mathrm{a}}=1.4-2 \times 10^{10} \mathrm{M}^{-1}\right)$. This may be due to a higher concentration of glycerol $(20 \%)$ in the solubilized extracts than in the membrane preparations (5\%). In mammals, results differ. Wimalasena et al. (1985) suggested that a $25 \%$ glycerol content in the porcine corpus luteum solubilized extract increased twofold both affinity constants and binding capacity of the $\mathrm{LH} /$ hCG receptor. Glycerol may increase binding activity with no change in affinity constants, indicating that glycerol itself has no effect on hormone-receptor interaction (Dias et al., 1981). In contrast, solubilization of mouse Leydig cells LH-hCG receptor, in the presence of glycerol $30 \%$ induced a twofold increase in the affinity of the receptors and no modification in their capacity (Ascoli, 1983). The present findings reveal that the higher concentration of glycerol may increase the GTH II receptor affinity and capacity. However, the affinity constants, before and after solubilization, were of the same order and largely concur with the constants previously described for sGTH II binding on membrane preparation for rainbow trout testes (Le Gac et al., 1988) and for brown trout ovaries (Breton et al., 1986). It was one or two orders of magnitude higher than the $K_{\text {a }}$ found in brown trout postovulatory ovary (Breton and Sambroni, 1989), in chum salmon granulosa cells (Salmon et al., 1984), in amago salmon intact follicles (Kanamori and Nagahama, 1988), and in the coho salmon postovulatory ovary (Yan et al., 1991).

The solubilized hormone-receptor complex was separated from the free-labeled hormone by gel filtration analysis. The gel filtration in a column calibrated with standard proteins did not permit the determination of the molecular weight of the complex. Indeed, the receptor-hormone complex coincided with the blue dextran marker so that the complex was probably adsorbed to the front marker. In the absence of blue dextran to avoid this adsorption, the complex was adsorbed within the gel and the bound radioactivity was spread.

The mammalian lutropin receptor has usually been purified by affinity chromatography with hCG. Procedures to purify the hCG-receptor complex by immunoaffinity chromatography with an antibody prepared against hCG, reported by Metsikkö and Rajaniemi (1980) and Jallal et al. (1988), give better yields than those obtained with direct affinity methods. The present study of the trout ovarian GTH II receptor reveals a purified hormone-receptor complex using a simple and rapid immunoaffinity chromatography on immobilized anti- $\beta$ GTH II gammaglobulins. The complex was partially dissociated by acidic $\mathrm{pH}$ elution; thus free GTH II receptor was also purified. About $50 \%$ of the Triton X-100 extract's binding activity was recovered in the $\mathrm{pH} 4$ eluate. The other binding sites were partially eluated as a GTH II- receptor complex and/or as a degraded form. When a fraction of the $\mathrm{pH} 4.0$ eluate was incubated with an excess of unlabeled GTH II, it resulted in a displacement amounting to $44 \%$.

In conclusion, the solubilization in a nonionic detergent in the presence of glycerol and purification by immunoaffinity chromatography isolated GTH II receptors with a yield of $50 \%$ with respect to initial binding activity. Fifty percent of the binding sites were thus likely to be intact, in spite of several degrading steps. The trout GTH II receptor thus seems to be a fairly stable protein.

\section{ACKNOWLEDGMENTS}

This work was supported in part by the French National Institute for Agronomic Research (INRA) and by a grant from the "Région Bretagne."

\section{REFERENCES}

Ascoli, M. (1983). An improved method for the solubilization of stable gonadotropin receptors. Endocrinology 113, 2129-2134. 
Breton, B., Jalabert, B., and Reinaud, P. (1976). Purification of gonadotropin from rainbow trout (Salmo gairdnerii Richardson) pituitary glands. Ann. Biol. Anim. Biochem. Biophys. 16(1), 25-36.

Breton, B., Fostier, A., Zohar, Y., Le Bail, P. Y., and Billard, R. (1983). Gonadotropine glycoprotéique maturante et oestradiol- $17 \beta$ pendant le cycle reproducteur chez la truite fario (Salmo trutta) femelle. Gen. Comp. Endocrinol. 49, 220-231.

Breton, B., Le Gac, F., and Sambroni, E. (1986). Gonadotropin hormone $(\mathrm{GtH})$ receptors in the ovary of the brown trout Salmo trutta L.: In vitro studies. Gen. Comp. Endocrinol. 64, 163-171.

Breton, B., and Sambroni, E. (1989). Evolution du nombre des récepteurs gonadotropes ovariens au cours du cycle reproducteur annuel chez la truite fario Salmo trutta L. C.R. Acad. Sci. (Paris) Sér. III 308, 495-500.

Dias, J. A., Huston, J. S., and Reichert, Jr. L. E. (1981). Effect of the structure-stabilizing agent glycerol on detergent-solubilized folliclestimulating hormone receptors from calf testis. Endocrinology 109, 736-742.

Dufau, M. L., Charreau, E. H., and Catt, K. J. (1973). Characteristics of a soluble gonadotropin receptor from the rat testìs. J. Biol. Chem. 248, 6973-6982.

Hirano, T., Prunet, P., Kawauchi, H., Takahashi, A., Ogasawara, T., Kubota, J., Nishioka, R. S., Bern, H. A., Takada, K., and Ishii, S. (1985). Development and validation of a salmon prolactin radioimmunoassay. Gen. Comp. Endocrinol. 59, 266-276.

Jallal, B., Salesse, R., Bidart, J. M., Martinat, N., Genty, N., and Garnier, J. (1988). Solubilization and purification of the lutropin (LH) receptor from porcine testes. Reprod. Nutr. Dev. 28 (4B), 1177-1192.

Kanamori, A., Kagawa, H., and Nagahama, Y. (1987). Gonadotropin receptors in the postovulatory ovary of amago salmon (Oncorhynchus rhodurus). Gen. Comp. Endocrinol. 66, 210-217.

Kanamori, A., and Nagahama, Y. (1988). Developmental changes in the properties of gonadotropin receptors in the ovarian follicles of amago salmon (Oncorhynchus rhodurus) during oogenesis. Gen. Comp. Endocrinol. 72, 25-38.

Keinänen, K. P., and Rajaniemi, H. J. (1986). Rat ovarian lutropin receptor is a transmembrane protein. Biochem. J. 239, 83-87.

Le Gac, F., and Fostier, A. (1987). Binding and action of $\mathrm{s}-\mathrm{GtH}$ on rainbow trout testis at various stages of gametogenesis. In "Proceedings 3rd International Symposium on Reproductive Physiology of Fish." St John's, Canada.

Le Gac, F., Breton, B., and Bougoussa, M. (1988). Gonadotropic hormone (GtH) receptors in the tes- tis of the trout salmo gairdneri: In vitro studies. Fish Physiol. Biochem. 5(4), 209-217.

Loosfelt, H., Misrahi, M., Atger, M., Salesse, R., Thi, M., Jolivet, A., Guiochon-Mantel, A., Sar, S., Jallal, B., Garnier, J., and Milgrom, E. (1989). Cloning and sequencing of porcine L.H-hCG receptor cDNA: Variants lacking transmembrane domain. Science 245, 525-528.

Lowry, O. H. (1951), Protein measure with the Folin phenol reagent. J. Biol. Chem. 195, 265-275.

Mc Farland, K. C., Sprengel, R., Phillips, H. S., Köhler, M., Rosemblit, N., Nikolics, K., Segaloff, D. L., and Seeburg, P. H. (1989). Lutropinchoriogonadotropin receptor: An unusual member of the $\mathrm{G}$ protein-coupled receptor family. $\mathrm{Sci}$ ence $245,494-499$.

Metsikkö, K., and Rajaniemi, H. (1980). Purification of luteinizing hormone receptor and its subunit structure. Biochem. Biophys. Res. Commun. 95, 1730-1736.

Minegishi, T., Nakamura, K., Takakura, Y., Miyamoto, K., Hasegawa, Y., Ibuki, Y., and Igarashi, M. (1990). Cloning and sequencing of human LH/hCG receptor cDNA. Biochem. Biophys. Res. Commun. 172, 1049-1054.

Nagahama, Y. (1983). The functional morphology of teleost gonads. In "Fish Physiology" (W. S. Hoar, D. J. Randall, and E. M. Donaldson, Eds.), Vol. IXA, pp. 223-275. Academic Press, New York.

Quesnel, H., and Breton, B. (1992). Solubilization and purification of the gonadotropin (GTH II) receptor from rainbow trout ovaries. $2^{\text {nd }}$ Int. Symposium on Fish Endocrinology, Saint Halo, June $1-4$.

Salmon, C., Kagawa, H., Adachi, S., Nagahama, Y., and Fontaine, Y. A. (1984). Mise en évidence de sites de liaison spécifique de la gonadotropine de Saumon chum (Oncorhynchus keta) dans des préparations membranaires de granulosa d'ovaire du Saumon amago (Oncorhynchus rhodurus). C.R. Acad. Sci. (Paris) Ser. III 298, 337-340.

Scatchard, G. (1949). The attraction of proteins for small molecules and ions. Ann. N.Y. Acad. Sci. $51,660-672$.

Schlaghecke, R. (1983). Binding of ${ }^{125} \mathrm{~J}-\mathrm{hCG}$ to rainbow trout (Salmo gairdneri) testis in vitro. Gen. Comp. Endocrinol. 49, $261-269$.

Schulz, R., and Schlaghecke, R. (1984). A receptor preparation from testes of Salmo gairdneri (Richardson): In vitro binding studies with ${ }^{125}$ I-labeled hCG and trout pituitary proteins. Gen. Comp. Endocrinol. 54, 132-138.

Schulz, R., Schlaghecke, R., and Blüm, V. (1985). A particulate membrane preparation from ovaries of preovulatory rainbow trout (Salmo gairdneri): 
binding studies with ${ }^{125}$ I-human chorionic gonadotropin. Comp. Biochem. Physiol. A 82, 429-433.

Steinbuch, M., and Audran, R. (1969). The isolation of IgG from mammalian sera with the aid of caprilic acid. Arch. Biochem. Biophys. 134, 279-284.

Thorell, J. I., and Johansson, B. G. (1971). Enzymatic iodination of polypeptides with ${ }^{125}$ I to high specific activity. Biochem. Biophys. Acta 251, 363-369.

Van Der Kraak, G., and Donaldson, E. M. (1982). Saturable gonadotropin binding sites in the testis and ovary of immature chum salmon. In "Proceedings of the International Symposium on Reproductive Physiology of Fish'' (C. J. J. Richter and H. J. Th. Goos, Eds.), Wageningen, The Netherlands, 2-6 August, 1982. Pudoc, Wageningen.

Van Der Kraak, G. (1983). An introduction to gonadotropin receptor studies in fish. In "Fish Physiology" (W. S. Hoar, D. J. Randall, and E. M. Donaldson, Eds.), Vol. IXA, pp. 405-441. Academic Press, New York.

Yan, L., Swanson, P., and Dickhoff, W. W. (1991). Binding of gonadotropins (GtH I and GtH II) to coho salmon gonadal membrane preparations. $J$. Exp. Zool. 258, 221-230.
Yan, L., Swanson, P., and Dickhoff, W. W. (1992). A two-receptor model for salmon gonadotropins (GtH I and GtH II). Biol. Reprod. 47, 418-427.

Young, G., Kagawa, H., and Nagahama, Y. (1983). Evidence for a decrease in aromatase activity in the ovarian granulosa cells of amago Salmon (Oncorhynchus rhodurus) associated with final oocyte maturation. Biol. Reprod. 29, 310-315.

Zohar, Y. (1982). L'évolution de la pulsatilité et des cycles nycthéméraux de la sécrétion gonadotrope chez la truite arc-en-ciel femelle en relation avec le cycle sexuel annuel et par rapport à l'activité stéroidogène de l'ovaire. Thèse d'état, PARIS VI.

Zohar, Y., Breton, B., and Fostier, A. (1986a). Shortterm profiles of plasma gonadotropin and estradiol-17 $\beta$ levels in the female rainbow trout, from early ovarian recrudescence and throughout vitellogenesis. Gen. Comp. Endocrinol. 64, 172-188.

Zohar, Y., Breton, B., and Fostier, A. (1986b). Shortterm profiles of plasma gonadotropin and $17 \alpha$-hydroxy-20 $\beta$-dihydroprogesterone levels in the female rainbow trout at the periovulatory period. Gen. Comp. Endocrinol. 64, 189-198. 